УДК 304.2+811:[811.11+811.161.2]

DOI https://doi.org/10.24919/2308-4863/43-3-24

\author{
Mariia SHUTOVA, \\ orcid.org/0000-0001-7210-0260 \\ Doctor of Linguistics, \\ Head of Professor G. Potcheptsov Department of Germanic and Finno-Ugrian Philology \\ Kyiv National Linguistic University \\ (Kyiv, Ukraine) mariia.shutova@knlu.edu.ua
}

\author{
Alina HOLINKO, \\ orcid.org/0000-0002-9173-9286 \\ Lecturer at the Department of English Language and Translation \\ Kyiv National Linguistic University \\ (Kyiv,Ukraine) alina.holinko@knlu.edu.ua
}

\title{
CORONAVIRUS PANDEMIC TOWARDS LINGUISTIC DISCOURSE: ENGLISH, GERMAN AND UKRAINIAN SOCIAL MEDIA RESPONSE
}

The article is dedicated to the precise analysis of the social networking websites' linguistic personality realization in English, German and Ukrainian digital environment. The article takes into account the disparity in terms of both English, German, Ukrainian social and cultural aspects, as well as behavior patterns from the sociolinguistic and digital dimension perspective. The aim is to identify, pinpoint and analyze both social and cultural dynamic of the information circulating on social networks with reference the pandemic and the distinguishing features of the response and users' behavior obtained from the English, German and Ukrainian audience. The materials acquired as a result of a careful data analysis of Google analytics, international and national scientific literary sources, social networking websites, information provided by the statistical portals and Internet-platforms, academic journals, blogs serve as the materials of our research. Based upon a precise analysis of the data of explanatory dictionaries of the English, German and Ukrainian languages, the tendency of creating linguistic mechanisms in the system of development of English, German and Ukrainian lexical environment was traced. The revaluation of everyday communication practices and daily living patterns occurred as a consequence of the COVID related public health restrictions and the essential measures taken to prevent the outbreak of the disease. The reconstruction of the semantic structure of lexical units with the nomination COVID enabled us to analyze the impact of the pandemic on the modern scientific paradigm of general linguistics, which manifests itself in the formation of new lexemes and idioms; in the change of semantics of already existing lexemes from secondary to primary nomination. The impact of the current pandemics towards the realization of linguistic personality in the English, German and Ukrainian languages has been proved. The investigations on the language studies arena, it was found out that the society tend to implement the euphemistic related devices and mild register stylistic notions in the discourse. The pandemic reflected not only our daily living patterns but the communication and behavior patterns as well as left the imprint in the digital dimension.

Key words: COVID, pandemic, comparative linguistics, social media, behavior patterns, semantic structure, nomination.

Марія ШУТОВА, orcid.org/0000-0001-7210-0260 доктор філологічних наук, дочент, завідувач кафедри германської і фіно-угорської філології імені професора Г. Г. Почепчова Київського національного лінгвістичного університету (Киї, Україна) mariia.shutova@knlu.edu.иa

\section{Аліна ГОЛІНКО, orcid.org/0000-0002-9173-9286} викладач кафедри англійської мови і перекладу Київського національного лінгвістичного університету (Київ, Украӥна) alina.holinko@knlu.edu.ua

\section{ПАНДЕМІЯ КОРОНАВІРУСУ У ЛІНГВІСТИЧНОМУ ДИСКУРСІ: РЕАКЦІЯ АНГЛІЙСЬКИХ, НІМЕЦЬКИХ ТА УКРАЇНСЬКИХ СОЦІАЛЬНИХ МЕРЕЖ}

Стаття присвячена детальному аналізу реалізації мовленнєвої особистості сайтів сочіальних мереж в англійському, німецькому та украйнському циифровому середовищі. У статті враховано невідповідність як англійських, німецьких, украӥнських соціальних та культурних аспектів, так і моделей поведінки з погляду сочіолінг- 
вістичного та ичфрового вимірів. Мета статті полягає у визначенні та аналізі як соціальної, так $і$ культурної динаміки інформації, щчо цчиркулює в соціальних мережах зі посиланням на пандемію. Водночас відмінні риси реакиії та поведінки користувачів, отримані від англійської, німецької та української аудиторії, прийняті до уваги. Матеріалами дослідження слугували дані, отримані в результаті ретельного аналізу бази даних аналітики Google, міжнародних та вітчизняних наукових літературних джерел, сайтів соціальних мереж, інформації статистичних порталів та Інтернет-платформ, академічних журналів, блогів. На основі аналізу даних тлумачних словників англійської, німецької та украӥнської мов простежено тенденцію створення лінгвістичних механізмів у системі розвитку англійського, німецького та українського лексичного середовища. Переоиінка повсякденних практик спілкування та буденного життя відбулася внаслідок обмежень, пов'язаних із COVID-19 у сфері охорони здоров'я, та основних заходів, вжитих для запобігання спалаху захворювання. Реконструкиія семантичної структури лексичних одиниць із номінацією COVID дала змогу проаналізувати вплив пандемії на сучасну наукову парадигму загального мовознавства, щчо проявляється у формуванні нових лексем та ідіом; у зміні семантики вже існуючих лексем із вторинної на первинну номінацію. Доведено вплив нинішньої пандемії на реалізацію мовленнєвої особистості англійською, німецькою та українською мовами. 3 'ясовано, шо суспільство схильне впроваджувати в повсякденне мовлення споріднені евфемістичні прийоми та менш експресивні стилістичні засоби. Пандемія відобразилася не лише на повсякденних моделях життя, а й на моделях спілкування та поведінки, а також залишила відбиток у циифровому вимірі.

Ключові слова: COVID, пандемія, порівняльне мовознавство, соціальні медіа, моделі поведінки, семантична структура, номінація.

Introduction. In the fast-growing world of communication, social media and social networks as means of mass communication play an increasingly significant role. Being a new way of communicative interaction, they have become the main source of news and information. Taking into consideration the rise in the use of phones, tablets, laptops and other gadgets, this trend is expected to be in the limelight for long, hence the question about the amount of time people spend in the web is not even rhetorical.

According to the Global Digital Overview unveiled by Hootsuite in 2020, every year people spend 10 minutes more in the Internet. It is alleged at this juncture an average Internet-user spends no less than 135 minutes a day in the social media, such as Facebook, TikTok, Instagram, LinkedIn, Google+, Twitter, Clubhouse, MySpace and the other blogs or social networking sites that help the Internet-surfers to create profiles and interact with people all over the world whilst exchanging the information of various content (Digital, 2020).

Reuters Institute Digital News Report asserted the impact of social media towards the society is highly underrated. Owing to the precise analysis of Reuters Institute Digital News Report it was figured out at least $43 \%$ of people find their news on social networks via getting messages from their friends or followers rather than through search engines (Neuer Wortschatz, 2020).

With reference to the data provided by Easy Media Internet-platform, $57 \%$ of the representatives of generation $\mathrm{Z}$ also concede they would rather click on a news link they received from someone they are already acquainted with rather than information that is associated with the other sources (even if they have already been aware of the other Internet-platforms before) (Matsko).
In the context of comparative linguistics, no attempts have been made to deliver an all-embracing review of the COVID pandemic influence in respect to the social networking websites' linguistic personality realization in English, German and Ukrainian digital environment, which determines the relevance of our research.

The aim of our investigation is to identify, pinpoint and analyze both social and cultural dynamic of the information circulating on social networks with reference the pandemic and the distinguishing features of the response and users' behavior it got from the English, German and Ukrainian audience.

The materials acquired as a result of a careful data analysis of Google analytics, international and national scientific literary sources, social networking websites, information provided by the statistical portals and Internet-platforms, academic journals, blogs serve as the materials of our research.

Theoretical Review. The works of such linguists as I. Holubovska, Yu. Karaulova, M. Kocherhan, O. Taranenko, V. Kostomarov, N. Sharmanov are devoted to the problems of the analysis of the constructs "disease" and "health" as a multifaceted phenomenon. The distinguishing features of linguistic representation of these terms were also considered from the standpoint of cognitology, culturology, lexical semantics, and semiotics by such scholars as O. Viktorina, O. Dunaievska, V. Krasnykh, O. Palchevska, L. Fedoriuk.

Having performed a precise analysis of the data of explanatory dictionaries of the English, German and Ukrainian languages, the tendency of creating linguistic mechanisms in the system of development of English, German and Ukrainian environment was traced.

With reference to the literature review, we took the heed of the scientific papers of such scholars as 
G. Lakoff, S. Herring, T. Erickson, M. Montgomery, D. Crystal, D. Graber, N. Fairclough, C. Honeycutt, H. Maturana, M. McLuhan and U. Meinhof as they addressed the issues of the distinguishing features and speech characteristics of language personality linguo-social modeling facets.

Results and Discussion. The New York Times compared the analytics of the global Internet usage with the pre-COVID and post-pandemics reality we face nowadays, revealing the way our behaviors have been altered (Matsko). Due to the discrepancies in the opinions of the authorities' representatives when the lockdown stagnation period comes to the end, people had to grapple with the relative communication obscurities that led to the unprecedented increase in the usage of messaging in social media websites. The COVID related public health restrictions and the essential measures taken to prevent the outbreak of the disease and diminish the transmission rates made a contribution to the daily living patterns and induced people all over the world make a revaluation of the everyday communication practices (Lawson, 2020). The limitations over the social gatherings make the individuals encompass the functions of the social media outlets to compensate the absence of the faceto-face interaction which extended to almost all European countries.

After the miscellaneous investigations on the language studies arena, it was found out that the English-speaking society tend to shift the emphatics in the communicative situations associated with the social distancing, isolation or stay-at-home orders. Real communication frontiers gave an impetus to the implementation of the euphemistic related devices and mild register stylistic notions in order to integrate the substitution of the coronavirus correlated designations (Shepherd, 2004: 88).

For instance, such nomination as "to be ill" was identified by the one which was altered, in both formal and informal digital correspondence the Internet-users substituted it by the notions "to feel not very well", "to prey to", "to martyr to" (Lutovinova, 2009: 74). Still, it also gave a chance to embrace one's creative and humorous side which make the others create unusual variants of notifying friends and colleagues one had been COVID-positive (Lawson, 2020). Instead of uttering "I have COVID" or posting the correspondent status on social networks, the users informed their followers about the adverse health condition by posting selfies with the caption underneath which sound as follows:

- "Congratulate me, I'm on my coronacation" (although initially the lexeme "coronacation" was a forced vacation when the office workers were staying at home not getting any money refund from their boss for taking several days, weeks or even months off in a row, it is also implied when one is infected with such a virus (Lawson, 2020). The German equivalent is "Ich bin auf die Corona-Reise gegangen" or "Ich have die Corona-Reise gemacht". It contains two units - "die Corona" and "die Reise", where the last can be translated into English as "journey" (Neuer Wortschatz, 2020). The Ukrainians have almost the identical ideas, as the Ukrainian word for the German "die Corona-Reise" and English "coronacation" sounds "koronapodorozh" (Matsko), which is related to the English variant more, as "podorozh" conveys a meaning "trip" or "tour" of any kind);

- "It's finally my turn to take part in the largest corona party ever" (despite the fact several months ago the lexical item "corona party" (the other English manifestations are "COVID party" and "lockdown party" correspondingly) was believed to stand for the gathering of people whose number reached such a level it was impossible not to get infected with a widespread disease, this particular seme has got one more meaning - it can be applied when too many COVID-infected individuals gathered in one room and do not have a choice but to stay with each other at least for two weeks (Lawson, 2020). There is a direct equivalent of the same phrase in the German language "die Corona-Party" (Duden, 2020), however, it is not mentioned with the same emphatics that often. The Ukrainian language also conveys the expression "koronavechirka" and even the variant related to the Slavic traditional gatherings - "koronavirusni vechornytsi" (Matsko), where the second seme was created from the word "evening" (Ukr. "vechir") that is widely used to refer to the festivities when the youngsters gathered together, seeking for the entertainment, dancing and music);

- "I'm in your quaranteam" ("quaranteam" refers to the people who share one accommodation during the epidemic - it is not of great significance whether the personalities knew each other before (Lawson, 2020). Also, it can be addressed to those who are now ill and "virtually" join the COVID-infected society. There is a connotation in the German language "der CoronaFreund" (concerns males) and "die Corona-Freundin" (deals with females only) that reflects the same sense. Moreover, in the German language there is even an abstract notion for such communication - it is called "die Corona-Freundschaft" that means "friendship during the COVID time" and is rather neutral Neuer Wortschatz, 2020). If one wants to sound more categoric, he or she can mention the word "die Infektionsgemeinschaft" that can be applied to the whole virtual COVID-community (Duden, 2020). It 
comprises two words - "infection" and "community", where the first one defines which feature the society members are united by);

- "Guess who is one more coronamember" ("coronamember" is the one who has already joined the "quaranteam" (Lawson, 2020));

- "I'll tell you a coronavirus joke now, but you'll have to wait two weeks to see if you got it" (if the previous collocations were typical for the English or German languages only, this one serves as an example how both the British and Ukrainians humor looks like);

- "Miss Rona checked me on" (sometimes the lexical item "Miss Rona" is replaced with the slang words "Corona Bae" or "Quarantine Babe" (Neuer Wortschatz, 2020; Kress, 2001). "Bae" is the English acronym for "before anyone else", it is another word for "honey", "sweetie" or "darling");

- "In two weeks I gonna take a reverse quarantine" (which conveys a sense one is ill right now, forced to stay at home, therefore he will do his best not to return home the next two weeks after being sure he can not infect the others anymore);

- "My weather for the next two weeks will be a room temperature" (the Internet-users are creating a lot of jokes based on the names of the most popular resorts among foreigners and combining different lexical items in a funny way. Therefore, the picture "Guess what will be your next destination - Las Kitchenas, Los Lounges, Santa Bedroomes, Porto Gardenas, Los bed, Costa Del Balconia, Sth bathroom, La Rotonda De Sofa" (Digital, 2020) gained such a popularity among Ukrainians, British and Germans that Amazon even started to sell the notebooks, posters and stickers with the same text item on);

- "For the next two weeks my hands will consume more alcohol than my mouth" (in this case alcohol refers to antiseptics);

- "Can not believe I will gain COVID-10 soon" (also known as "quarantine 15", this one is popular because of the funny rhyme one can create (Lawson, 2020); we can draw the allusion to the commonly used first-students' expression "freshman 15" that concerns the amount of weight the disciples get during their first year either at college, or any other educational institution. The result of such an unusual weight gain is the irregular food supply, enormous alcohol intake, new living conditions one needs to get used to, no physical exercises and the increased level of stress. It appears that coronavirus has a profound impact on a patients' life as well, accordingly, the increased sitting time, no possibilities to take a stroll, stresseating and poor mental health also leads to the same consequences. If the Ukrainians do not seem to have the correspondences to such a phrase, the German equivalent is "der Coronaspeck". It is composed of two words - "die Corona" and "der Speck", which can be translated into English as "Corona bacon" or "Corona fat" (Neuer Wortschatz, 2020). If "COVID-10" refers to weight one can get having no choice but to stay at home because of the symptoms the doctors or medical staff have detected, the Germans can apply this variant whilst discussing the weight they got after getting a habit of eating more than usual due to the work from home initiatives. The fact worth our attention is the number of jokes one can find on the net - "If I keep stress-eating at this level, the buttons on my shirt will start socially distancing from each other").

There are several collocations and set expressions that have nothing in common with the English and German set expressions - one of the most widespread utterance on the Ukrainian social networking sites is "Atlant zataryv hrechi" (Ukr. "Atlant bought some buckwheat"), which is a pun to the name of the famous book of Ayn Rand "Atlas Shrugged" (the twist is in Ukrainian the title of the novel sounds "Atlant rozpravyv plechi" that creates a funny rhyme with the previous variations, created by the Internet-users) (Matsko). In such a way the individuals mock at the fact they had bought a strategic product and now feel safe - food the Ukrainians can not imagine their life without. In spite of the fact it is not always used in all the cases as the way how to let the others know one is infected, still, this status gained momentum on different digital Ukrainian platforms. The German web-users also have similar puns related to the food and dishes - one of the posts that became viral sounded 'I'm ill, I've got the Wurst Käse scenario". It is unusual that in this sentence two languages are mixed - the first part is written in English, meanwhile two German words "der Käse" (Eng, "cheese") and "die Wurst" (Eng. "sausage") are inserted (Duden, 2020). The author of the phrase did it on purpose as it sounds almost identical to the English "I've got the worst scenario" which does not have anything to do with bad or sad news - it highlights one has bought a large amount of products beforehand not to worry about anything.

Sometimes the expressions mentioned are so convoluted it is difficult to identify one is intended to report about the changes in his or her health outcomes. For examples, the English phrase "Never thought the big weekend can make me so sad" (Lawson, 2020) or the Ukrainian respond 'It's a matter of taste, perhaps, so can't give you a comprehensive answer" (Matsko), where "big weekends" give a slight clue the days off do not make a person happy and "it's a matter of taste" touches on the symptoms of COVID (namely, loss of taste and smell).

The interesting fact is that the posts about recovery are also accompanied by the expressions of the figurative language one sticks to in order to reach 
the others out with good news. The semes "I have recovered" are replaced with the unusual "You've had your fun, Rona, but the party's over" (Lawson, 2020) (the German correspondence sounds "Meine CoronaPartys beendet haben" (Duden, 2020), "2020 / 2021 is the strictest parent I've ever had but now I am", "I've escaped my 2 weeks Corona prison" (Lawson, 2020).

The conducted scientific research allows to draw the following conclusions. The reconstruction of the semantic structure of lexical units with the nomination "COVID" enabled us to analyze the impact of the pandemic on the modern scientific paradigm of general linguistics, which manifests itself in the formation of new lexemes and idioms; in the change of semantics of already existing lexemes from secondary to primary nomination. The pandemic is also reflected in the new behavior of communicators. New rules of etiquette were formed and established. The quarantine put native speakers into new conditions, which influenced not only the statuses in social networks, but also the least manifestation of situational humour types in official and business discourse, as well as the formation of neologisms and idioms. Real communicative boundaries have given rise to the introduction of euphemistic means and stylistic concepts of soft register to integrate the substitution of denotations correlated with the coronavirus. the article traces the realization of linguistic personality in the English, German and Ukrainian languages. The pandemic reflected not only our daily living patterns but the communication and behavior patterns as well left a footprint in the digital dimension.

The prospect of further research is to consider the implementation of "COVID" concept from another sociolinguistic perspective and make a comparative analysis of the same notions in the other languages.

\section{СПИСОК ВИКОРИСТАНИХ ДЖЕРЕЛ}

1. Лутовинова О. Лингвокультурологические характеристики виртуального дискурса. Волгоград : Перемена, 2009. $476 \mathrm{c}$

2. Мацько О. Досить шастати: чому мова не йде на карантин. Weekend Today. URL: https://projects.weekend.today/ language quarantine (last access 30.10.2021)

3. Bateman J. Multimodality and Genre: A Foundation for the Systematic Analysis of Multimodal Documents. Elsternwick: Insight Publications, 2008. 312 p.

4. Das Online-Wortschatz-Informationssystem Deutsch des Instituts für Deutsche Sprache. Neuer Wortschatz rund um die Coronapandemie. 2020. [New vocabulary about the corona pandemic]. URL: https://www.owid.de/docs/neo/listen/ corona.jsp\# (last access 30.10.2021)

5. Digital 2020: Global digital overview. Hootsuite. URL: https://datareportal.com/reports/digital-2020-global-digitaloverview (last access 27.10.2021)

6. Duden Wörterbuch Online. Neue Wörter durch Krise "Covid-19" bald im Duden? 2020. [New words due to the crisis "Covid-19" soon in the Duden?]. URL: https://www.tagesschau.de/inland/corona-duden-101.html (last access 26.10.2021).

7. Kress G., T. van Leeuwen. Multimodal Discourse: The Modes and Media of Contemporary Communication. London: Hodder Arnold Publication, 2001. 152 p.

8. Lawson R. Coronavirus has led to an explosion of new words and phrases - and that helps us cope. The Conversation, 2020. URL: https://theconversation.com/coronavirus-has-led-to-an-explosion-of-new-words-and-phrases-and-that-helps-uscope-136909 (last access 27.10.2021).

9. Shepherd J. What is the Digital Era? Berkley: University of California Press, 2004. $18 \mathrm{p}$.

10. Simpson J. The Routledge Handbook of Applied Linguistics. London: Routledge, 2011. 752 p.

\section{REFERENCES}

1. Lutovinova O. Lingvokulturologicheskiye harakteristiki virtualnogo diskursa [Linguo-culturological features of online discourse]. Volgograd : Peremena. 2009. 476 p. [in Russian].

2. Mats'ko O. Dosyt shaststy: chomu mova ne ide na karantyn. [Stop walking: the language is not on quarantine]. Weekend Today. URL: https://projects.weekend.today/language quarantine (last access 30.10.2021) [in Ukrainian].

3. Bateman J. Multimodality and Genre:AFoundation for the Systematic Analysis of Multimodal Documents. Elsternwick: Insight Publications, 2008. 312 p.

4. Das Online-Wortschatz-Informationssystem Deutsch des Instituts für Deutsche Sprache. Neuer Wortschatz rund um die Coronapandemie. 2020. [New vocabulary about the corona pandemic]. URL: https://www.owid.de/docs/neo/listen/ corona.jsp\# (last access 30.10.2021) [in German].

5. Digital 2020: Global digital overview. Hootsuite. URL: https://datareportal.com/reports/digital-2020-global-digitaloverview (last access 27.10.2021)

6. Duden Wörterbuch Online. Neue Wörter durch Krise "Covid-19" bald im Duden? 2020. [New words due to the crisis "Covid-19" soon in the Duden?]. URL: https://www.tagesschau.de/inland/corona-duden-101.html (last access 26.10.2021) [in German].

7. Kress G., T. van Leeuwen. Multimodal Discourse: The Modes and Media of Contemporary Communication. London: Hodder Arnold Publication, 2001. 152 p.

8. Lawson R. Coronavirus has led to an explosion of new words and phrases - and that helps us cope. The Conversation, 2020. URL: https://theconversation.com/coronavirus-has-led-to-an-explosion-of-new-words-and-phrases-and-that-helps-uscope-136909 (last access 27.10.2021).

9. Shepherd J. What is the Digital Era? Berkley: University of California Press, 2004. 18 p.

10. Simpson J. The Routledge Handbook of Applied Linguistics. London: Routledge, 2011. 752 p. 